\title{
Dynamics of Hume's Law ${ }^{\#}$
}

\section{David Martinčík - Blanka Šedivá*}

"Suppose four-fifths of all the money in GREAT BRITAIN to be annihilated in one night, and the nation reduced to the same condition, with regard to specie, as in the reigns of the HARRYS and EDWARDS, what would be the consequence? Must not the price of all labour and commodities sink in proportion, and every thing be sold as cheap as they were in those ages? What nation could then dispute with us in any foreign market, or pretend to navigate or to sell manufactures at the same price, which to us would afford sufficient profit? In how little time, therefore, must this bring back the money which we had lost, and raise us to the level of all the neighbouring nations? Where, after we have arrived, we immediately lose the advantage of the cheapness of labour and commodities; and the farther flowing in of money is stopped by our fulness and repletion." (Hume, 1752b)

\section{Introduction}

The Hume's Law is one of the oldest theories of the balance of payment adjustment mechanism. Author - David Hume (1711-1776) - published his theory in 1752 in the book Essay, Moral, Political and Literary - part II Political Discourses; concrete in Essay V: Of the Balance of Payment. The basic idea of the adjustment mechanism is quite simple: If a country shows the surplus of export out, it implies the inflow of money from the rest of the world into this country. The rising money stock induces (in agreement with the quantitative theory of money) a rising of the price level and then the domestic goods loose the competitive advantage and export diminishes. The money increase (or decrease) according to actual surplus of export or import and according to corresponding changes of the price level equalize the balance of payment. This mechanism is often called as price-specie-flow mechanism too.

It is evident that the mechanism is operating under the gold standard if you like under the fixed FX system and deals only with the trade balance and does not deal with the whole balance of payment so the international capital markets and movements don't exist. The diminishing of value of export induced by rising domestic price level requires fulfilment of the Marshall-Lerner condition which doesn't need to be satisfied in short run. Hume, likewise the whole generation of classical political economy coming after him, didn't consider the impact the domestic country on the rest of the world so they thought the small open economy in effect. Hume and e.g. Smith overlooked the possibility that Britain money flows might be on a sufficiently large scale relative to the "monetary size" of the rest of the world to influence the price level in it. The critics of this can we find e.g. in Fetter (1965, p. 10).

The support from the Ministry of Education, Youth and Sports of the Czech Republic under the grant LC06075 is gratefully acknowledged.

JUDr. Ing. David Martinčík - research fellow; Department of Economics and Finance, Faculty of Economics, University of West Bohemia, 30614 Plzeň, Univerzitní 8, Czech Republic; martinci@kef.zcu.cz.

Mgr. Blanka Šedivá, Ph.D. - research fellow; Department of Mathematics, Faculty of Applied Science, University of West Bohemia, 30614 Plzeň, Univerzitní 8, Czech Republic; sediva@kma.zcu.cz. 


\section{Simple discrete model}

The simplest exposition (textbook exposition) of Hume's Law in a small economy can be described in this equations system:

$$
\begin{aligned}
& M=k P Y, \\
& \Delta M=N X_{N}=\alpha\left(P_{W}-P\right),
\end{aligned}
$$

where $N X_{N}-$ nominal net export,

$P_{W}-$ constant aggregate price level of the rest of the world,

$\alpha$ - parameter of sensitiveness, the speed of reaction (adjustment); there is the concrete dimension of this parameter (moneyed unit of net export induced by one unit of international price differential); ( $\alpha>0$ according the Marshall-Lerner condition).

The equation (1) is the money market balance, left side is the nominal money stock and the right side is the money demand in "Cambridge" form. The equation (2) shows the dependence of value of the net export (the nominal trade balance) on the "international price differential"; $\alpha * P_{W}$ is the autonomous nominal net export dependent on the constant price level of the rest of the world. The identity of money (gold) flows and nominal net export is incorporated. The solution of this system is:

$$
M_{t}=\left(M_{0}-P_{W} k Y\right) \cdot\left(1-\frac{\alpha}{k Y}\right)^{t}+P_{W} k Y,
$$

where $M_{0}$ - initial condition.

The divergence or convergence of the system depends on the item $(\alpha / k Y)$, too high value of a leads to divergence. All possibilities are shown in the following table:

Table 1: Convergence and divergence in dependence on the item $(\alpha / k Y)$

\begin{tabular}{|l|l|}
\hline$\alpha / k Y$ & Behaviour of the model \\
\hline 0 & $N X_{N}$ keeps by the initial level (don't equalize) and $M$ changes constantly \\
\hline$(0,1)$ & $N X_{N}$ equalizes by monotonous trajectory \\
\hline 1 & $N X_{N}$ balances in first period at once \\
\hline$(1,2)$ & $N X_{N}$ equalizes by oscillated trajectory \\
\hline 2 & $N X_{N}$ oscillates periodically (don't equalize) \\
\hline$>2$ & $N X_{N}$ oscillates with increasing deviation (don't equalize) \\
\hline
\end{tabular}

The convergence is established in case $(\alpha / k Y) \in(0,2)$. Then the equilibrium state is $P=P_{W}$.

The small economy can't inflow the world parameters then $P_{W}$ is constant. The system can be modified for the large economy, to the equations (1) and (2) is appended the equation (4):

$$
T-M=k_{W} P_{W} Y_{W},
$$

where $T-$ total world money (gold) stock,

$W$ - index "rest of the world". 
The equations (1) and (4) represent the money market balance in domestic country and in the rest of the world. We observe the trade balance only between domestic country and the rest of the world so the equation (2) is sufficient. The identity of the increase of the money in domestic country and its nominal net export surplus is incorporated there. The solution of this simple discrete model for large economy is following:

$$
M_{t}=\left(M_{0}-C\right) \cdot\left(1-\alpha\left(\frac{1}{k Y}+\frac{1}{k_{W} Y_{W}}\right)\right)^{t}+C,
$$

where $\quad C=\frac{T k Y}{k Y+k_{W} Y_{W}}$.

The convergence of solution (5) is established in case $\alpha\left(\frac{1}{k Y}+\frac{1}{k_{W} Y_{W}}\right) \in(0,2)$ and we can interpret the behaviour of the model analogically as in tab. 1 . The equilibrium state is $P=P_{W}$ and $M / M_{W}=k Y / k_{W} Y_{W}$ where $M_{W}=T-M$.

The large economy model is more general because if $Y_{W} \rightarrow \infty$ and we made suitable choose of the constant item ${ }^{1}$, the equations (3) and (5) can be identical. The discrete model is acceptable in case when the international trade proceeds in separated delivery round by another name when the international trade is controlled by only one (or a few) large firm. In the case international trade is preformed by a lot of subjects, is preferable the continuous model; the acceptability of model advises e.g. Allen (1971, p. 39).

\section{Simple continuous models}

The simplest continuous model for small economy consists of two equations. The first equation (1) describes the behaviour of economy according to quantitative theory of money and the second equation is continuous international adjustment (6):

$$
\dot{M}=N X_{N}=\alpha\left(P_{W}-P\right)
$$

and the solution of this system is:

$$
M_{t}=\left(M_{0}-P_{W} k Y\right) \cdot \exp \left(-\frac{\alpha}{k Y} t\right)+P_{W} k Y \text {. }
$$

The model for large economy is (1), (4) and (6).

And the solution is:

1 The verification of this proposition is available in Martinčík (2006). 
The equilibrium state is $P=P_{W}$ and $M / M_{W}=k Y / k_{W} Y_{W}$ where $M_{W}=T-M$. Because Hume didn't write about income velocity of money or he considered it to be $1^{2}$, the equilibrium ratio of money stocks in domestic country and the rest of the world equals to ratio of real products in domestic country and the rest of the world in Hume's case.

In these models (of one differential equation) is stabilization warranted ${ }^{3}$. It isn't realistic to assume that the domestic price level adjusts the money stock immediately. So we have to consider the delay of price adjustment to the new money stock and the system of the small economy changes to (the identity of money in/out flows and nominal net export is fail):

$$
\begin{aligned}
& \dot{M}=\alpha\left(P_{W}-P\right), \\
& \dot{P}=\beta(M-k P Y),
\end{aligned}
$$

where $\beta$ - parameter of adjustment the domestic price level to the new money stock

The equilibrium state is the same as in the one differential equation model. The Jacobian matrix and the eigenvalues of characteristic equation are:

$$
\begin{aligned}
& J=\left[\begin{array}{cc}
0 & -\alpha \\
\beta & -\beta k Y
\end{array}\right], \\
& \lambda_{1,2}=\frac{-\beta k Y \pm \sqrt{\beta^{2} k^{2} Y^{2}-4 \alpha \beta}}{2} .
\end{aligned}
$$

If $\beta k^{2} Y^{2}<4 \alpha$ there are complex roots of the characteristic equation and the system converges to the equilibrium state slowly with considerable cyclic components. This can be case of too small economy - very low real product. The behaviour of this model is demonstrated for the parameters $\alpha=\beta=0,1 ; k=1 ; Y=0,01 ; P_{W}=1$ (the inequality $\beta k^{2} Y^{2}<4 \alpha$ is fulfilled) and initial conditions of domestic money stock and domestic price level were chosen between 0,2 and 1,4. Fig. 1 presents the phase portrait.

2 We owe one of the reviewers the notice that Hume could understand the dynamic of quantitative theory as absolute change of money stock and absolute changes of nominal product whereas the velocity of money is constant i.e. $\Delta M \cdot V=\Delta(P \cdot Y)$ and the velocity of money could be different from 1 .

3 If the Marschall-Lerner condition is fulfilled i.e. $\alpha>0$. 
Figure 1: Phase portrait of small economy and price level $P(t)$
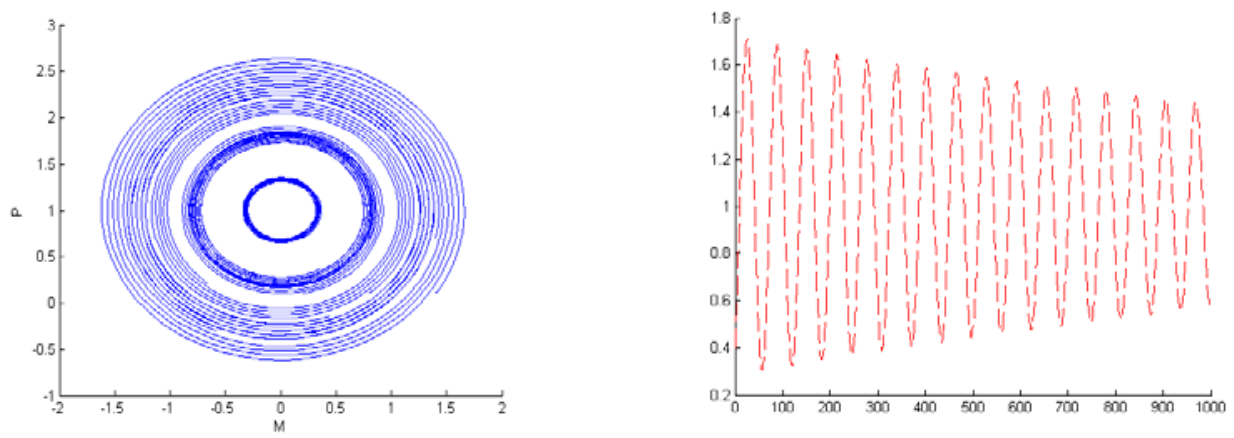

The modification of this model to large economy requires adding to the equations (9) and (10) the third equation of difference of the price level of the rest of the world (13):

$$
\dot{P}_{W}=\beta_{W}\left(T-M-k_{W} P_{W} Y_{W}\right)
$$

where $\beta_{W}$ - parameter of adjustment the "world" price level to the new money stock

The equilibrium state is the same over again. The Jacobian matrix:

$$
J=\left[\begin{array}{ccc}
0 & -\alpha & \alpha \\
\beta & -\beta k Y & 0 \\
\beta_{W} & 0 & -\beta_{W} k_{W} Y_{W}
\end{array}\right] .
$$

The demonstration of this model under the same conditions shows that the large economy with influence of the rest of the world could be stabile behaviour. The parameters are $\alpha=\beta=\beta_{W}=0,1 ; k=k_{W}=1 ; Y=0,01 ; Y_{W}=1 ; T=2$. The initial conditions for $M, P$ and $P_{W}$ were selected as 0,2 and 0,6 (i.e. total 8 trajectories). Fig. 2 presents the dynamics of domestic money stock and Fig. 3 presents the 3D phase portrait.

Figure 2: Domestic money stock

Figure 3: Phase portrait
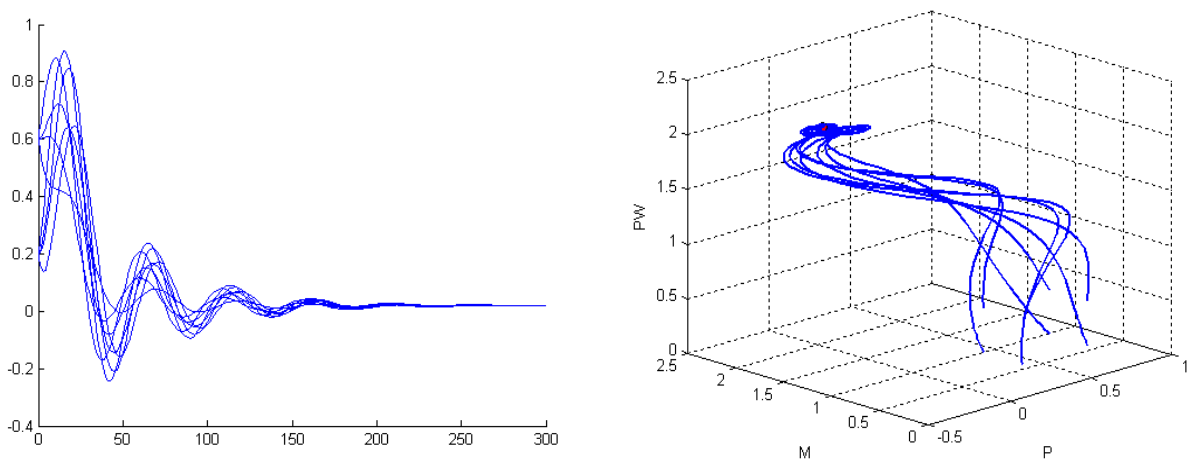
The presented models considered constant real product in domestic economy and also in the rest of the world i.e. the continuous equilibrium on labour markets and potential products. But Hume's thought wasn't so pure "monetary".

\section{Correct Hume's model}

Hume hadn't such orthodox opinion in the neutrality of money as he is nowadays presented. He was conscious of the transition period between the increase of money stock and the rise of prices in the economy. In the essay Of Money he wrote: "But notwithstanding this conclusion (neutrality of money - rem. D.M and B.Š), which must be allowed just, it is certain, that, since the discovery of the mines in AMERICA, industry has encreased in all the nations of EUROPE, except in the possessors of those mines; and this may justly be ascribed, amongst other reasons, to the encrease of gold and silver. Accordingly we find, that, in every kingdom, into which money begins to flow in greater abundance than formerly, every thing takes a new face: labour and industry gain life; the merchant becomes more enterprising, the manufacturer more diligent and skilful, and even the farmer follows his plough with greater alacrity and attention. This is not easily to be accounted for, if we consider only the influence which a greater abundance of coin has in the kingdom itself, by heightening the price of commodities, and obliging every one to pay a greater number of these little yellow or white pieces for every thing he purchases. And as to foreign trade, it appears, that great plenty of money is rather disadvantageous, by raising the price of every kind of labour." (Hume, 1752a)

So it is obvious that Hume's thinking was more sophisticated and the correct Hume's model must contain variable product depend on the changes in money stock. To the small economy model (9) and (10) we add the third differential equation (15):

$$
\dot{Y}=\gamma\left(\frac{M}{k P}-Y\right),
$$

where $\quad \gamma$-parameter of adjustment the domestic real product to the money stock

The principle of adjustment mechanism is the same so the equilibrium state is $P=P_{W}$ and $M / M_{W}=k Y / k_{W} Y_{W}$ of course. Because $Y$ is variable now, it is the multiple equilibrium point of variable $Y$ and $M$ too. The Jacobian matrix of the system follows:

$$
J=\left[\begin{array}{ccc}
0 & -\alpha & 0 \\
\beta & -\beta k Y & -\beta k P \\
\gamma / k P & -\gamma M / k P^{2} & -\gamma
\end{array}\right] .
$$

The numerical demonstration of model behaviour is performing under as much as possible similar parameters $\alpha=\beta=\gamma=0,1 ; k=1 ; P_{W}=1$. The initial conditions for

\footnotetext{
4 Keynes commented this Hume's passage: „...For Hume began the practice amongst economists of stressing the importance of the equilibrium position as compared with the ever-shifting transition towards it, though he was still enough of a mercantilist not to overlook the fact that it is in the transition that we actually have our being: It is only in this interval or intermediate situation, between the acquisition of money and a rise of prices, that the increasing quantity of gold and silver is favourable to industry. ...” (Keynes, 1936)
} 
$M, P$ and $Y$ were selected as 0,4 and 0,6 (i.e. total 8 trajectories). Fig. 4 presents dynamics of price level, Fig. 5 presents dynamics of real product and Fig. 6 presents dynamics of money stock and also this picture presents the dynamics of trade balance (we use the equality $\Delta M=N X$ or $\dot{M}=N X$ ).

Figure 4: Price level

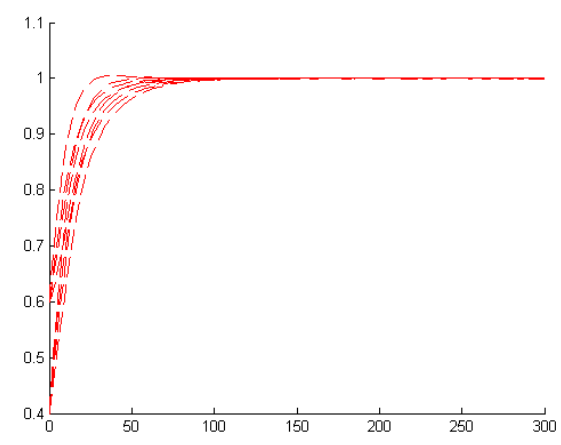

Figure 5: Real product

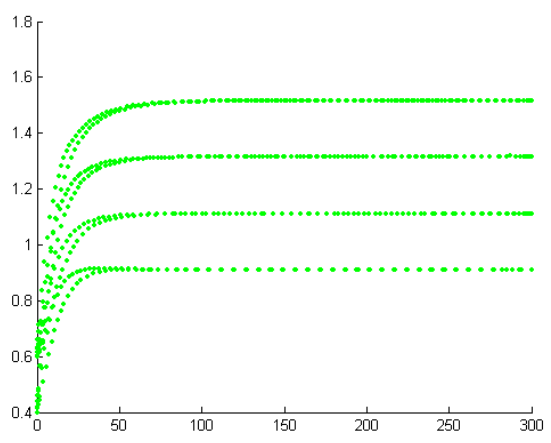

Figure 6: Money stock $(\Delta M=N X)$

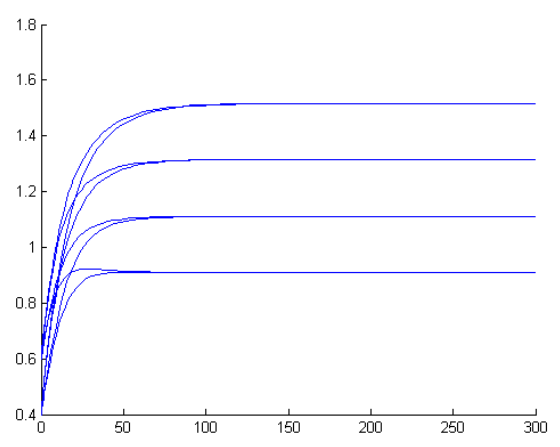

While the price level of the small country converges to the price level of the rest of the world, the equilibrium level of real product depends on the initial condition. This transition phase will take as long as the labour market equilibrium process gets the production back to potential. It was uncovered that the Hume's adjustment mechanism could be the source of instability in short run.

The model modification for large economy is analogous. To the equations system (9), (10), (13) and (15) we add the equation (17):

$$
\dot{Y}_{W}=\gamma_{W}\left(\frac{T-M}{k_{W} P_{W}}-Y_{W}\right),
$$

where $\gamma_{W}$ - parameter of adjustment the "world" real product to the new money stock.

The equilibrium state responds the small economy case $P=P_{W}$ and $M / M_{W}=k Y / k_{W} Y_{W}$. The Jacobian matrix follows: 


$$
J=\left[\begin{array}{ccccc}
0 & -\alpha & \alpha & 0 & 0 \\
\beta & -\beta k Y & 0 & -\beta k P & 0 \\
-\beta_{W} & 0 & -\beta_{W} k_{W} Y_{W} & 0 & -\beta_{W} k_{W} P_{W} \\
\gamma / k P & -\gamma M / k P^{2} & 0 & -\gamma & 0 \\
-\gamma_{W} / k_{W} P_{W} & 0 & -\gamma_{W}(T-M) / k_{W} P_{W}^{2} & 0 & -\gamma W
\end{array}\right]
$$

The numerical demonstration of behaviour of the large economy model is performing under parameters $\alpha=\beta=\beta_{W}=\gamma=\gamma_{W}=0,1 ; k=k_{W}=1 ; T=1$. The results for the initial conditions for $M, P, Y, P_{W}=0,2$ and 0,4 and for $Y_{W}=1,2$ and 1,4 (i.e. total 32 trajectories) are presented on the Fig. 7 up to Fig. 11.

Figure 7: Domestic price level

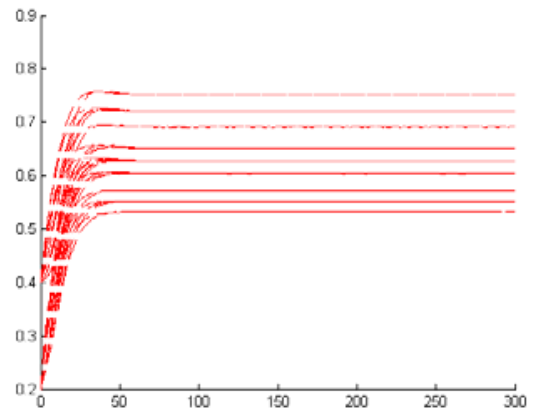

Figure 8: Domestic real product

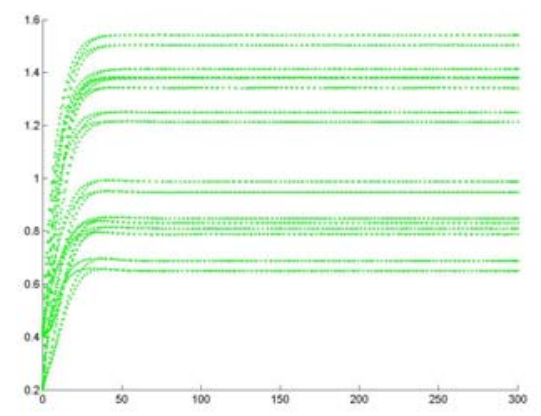

Figure 9: World price level

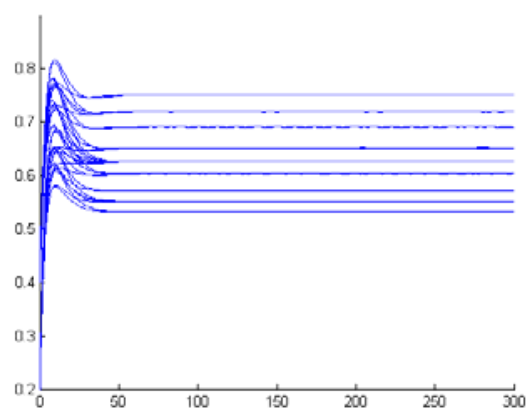

Figure 10: World real product

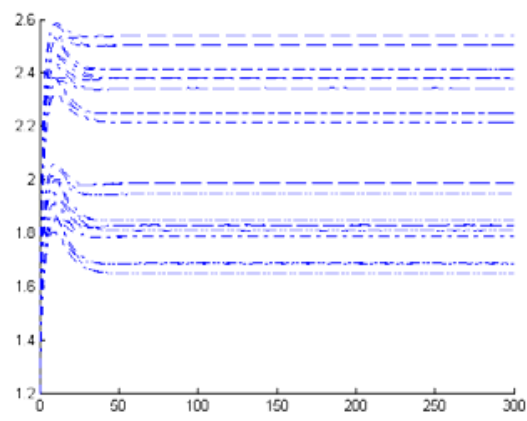

Figure 11: Domestic money stock $(\Delta M=N X)$

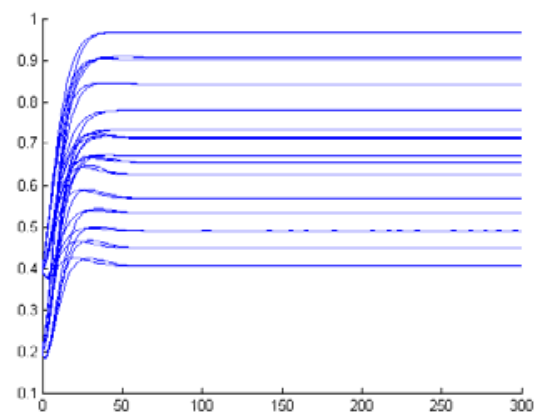


The behaviour of the large economy model is under selected parameters similar the behaviour of the small economy model. In the graphs there is noticeable that the stabilization is faster in large economy model.

\section{Conclusion}

The price-specie-flow adjustment mechanism of trade balance (Hume's Law) requires the fulfilment of the Marshall-Lerner condition. The continuous one differential equation model converges direct to equilibrium state. The model with delay of price adjustment to the quantity of money could be unstable in case too low real product in watched country. This instability problem partially solves the inclusion of the influence of the watched economy on the price level and money stock in the rest of the word. The large economy model (i.e. model with this influence) is always generally than the one of small economy. But Hume didn't believe the neutrality of money in short run. So the model must be extended by equation where real product is next delayed variable. This leads to multiple equilibrium of the real product and money stock, the concrete attained level depends on the initial conditions. The Hume's Law could be during the transition period the source of instability of the real sector of economy.

\section{References}

[1] ALLEN, G. R. D. (1971): Matematická ekonomie. Praha : Academia, 1971.

[2] FETTER, F. W. (1965): Development of British Monetary Orthodoxy 1797-1875. Cambridge : Harvard Press, 1965.

[3] HUME, D. (1752a): Essay, Moral, Political and Literary, part II Political Discourses. Essay III. Of Money. [on-line], Liberty Found, Inc. 1987, [cit: 24.3.2007],

$<$ http://socserv2.socsci.mcmaster.ca/ econ/ugcm/3113/hume/money.txt $>$.

[4] HUME, D. (1752b). Essay, Moral, Political and Literary, part II Political Discourses. Essay V. Of The Balance of Trade. [on-line], Liberty Found, Inc. 1987, [cit: 24.3.2007], <http://socserv2.socsci.mcmaster.ca/ econ/ugcm/3113/hume /trade.txt>.

[5] KEYNES, J. M. (1936): The General Theory of Employment, Interest and Money. Cambridge : Macmillan Cambridge University Press, 1936.

[6] MARTINČÍK, D. (2006): Dynamika Humeova zákona, připad malé a velké zemé. In European Scientific Conference of PhD. Students MendelNet $29^{\text {th }}$ November 2006, Brno, Mendel University of Agriculture and Forestry in Brno, 2006, s. 176. 


\title{
Dynamika Humeova zákona
}

\section{David Martinčik - Blanka Šedivá}

\begin{abstract}
Abstrakt
David Hume zformuloval nejstarší přizpůsobovací mechanismus platební bilance již $\mathrm{v}$ roce 1752. V tomto mechanismu je zahraniční obchod citlivý na rozdíl mezi domácí a zahraniční cenovou hladinou - proto se nazývá cenový. I když podobně jako celá následující generace ekonomů v rámci klasické politické ekonomie přehlédl vliv tehdy skutečně velké britské ekonomiky na ekonomické proměnné ostatního světa a v podstatě vyvinul model pro malou zemi, v jeho díle je další zajímavý problém. Ačkoliv je Humeovi připisováno autorství (nikoliv prvenství) kvantitativní rovnice peněz, nebyl představitelem čistého monetarismu resp. neutrality peněz a byl si velmi dobře vědom přechodného období, kdy změna peněžní zásoby působí na reálné proměnné ekonomiky. Proto je nutné opustit model s konstantním reálným produktem. Variabilita reálného produktu $\mathrm{v}$ prezentovaném model vede $\mathrm{k}$ možnosti vytvoření různých stabilních úrovní peněžní zásoby a reálného produktu podle počátečních podmínek. V přechodném období (neneutrality peněz) tak může být cenový vyrovnávací mechanismus, podle názoru autorů, dokonce zdrojem nestability reálného sektoru ekonomiky.
\end{abstract}

Klíčová slova: Humeův zákon; neutralita peněz; přechodné období.

\section{Dynamics of Hume's Law}

\begin{abstract}
David Hume formulated the oldest theory of balance of payment adjustment mechanism in 1752. In his model foreign trade is sensitive to the difference between the home and foreign price levels and that is why it is also called price - specie - flow mechanism. Hume, likewise the whole generation of classical political economists coming after him, failed to see the impact of then strong British economy on economic variables of the rest of the world and in effect he developed a model for a small economy. Although the authorship of the quantitative monetary equation is ascribed to him, Hume did not represent pure monetarism, i.e. neutrality of money. He was well aware of the transition period, during which a change in money stock affect the real economics variables. For this reason it is necessary to abandon the constant real product model. Variability of the real product in the presented models makes it possible to create different stable levels of money stock and the real product in accordance with the initial conditions. The authors are of the opinion that the balance of payment adjustment mechanism can thus be source of instability of the real sector of the economy.
\end{abstract}

Key words: Hume's Law; neutrality of money; transition period.

JEL classification: B22, E31, F41. 